\title{
LANGUAGE AND CULTURE: CONTEXTS IN BRITISH ENGLISH AND IRAQI ARABIC
}

\author{
Mohammed A. Ali Al Fuadi \\ English department, Open Educational College, Ad-Diwaniya Centre, \\ general directorate of education in Ad-Diwaniya, \\ Ministry of Education, Republic of Iraq
}

\begin{abstract}
The use of language in interaction entails more than simply exchanging information about realistic ideas and objects amongst people; it is an important process, in which the relationships among people have outlined and negotiated. Any language refers to a particular culture, so learning any language does not mean learning only the grammar and the vocabulary of this language, but in fact, it is learning the behaviour and the customs of society as well as the characteristics that distinguish this community from others. There are no similar languages to the same extent as the social reality. We know that being aware of the culture is like being aware of the language so that we know that they are homogeneous psychological facts. Communication between people happens through direct linguistic messages and other messages that denoted by cultural features that are only understanding through the knowledge of the patterns specific to the society that produced them. The ideal and complex relationship between language and culture shows us that language is closely related to culture that influences each other, develops together and ultimately forming what it is to be human. Therefore, taking part in conversations, people consciously or unconsciously show their identities, their belongings to a specific culture or group and also their tendencies to become close or distant from others. By using language, people define their relationships to each other and identify themselves as part of a social group, implying that language is culture and culture is language.
\end{abstract}

Key words: cultural communication, customs, cultural differences, socio-pragmatics, notion of face

\section{INTRODUCTION}

Not only language conveys direct meanings by words and structures, but also it carries the culture of its speakers. Our interaction with language represents interaction with the culture represented by it. Thus, "Language communicates through culture and culture also communicates through language".

This article tries to contribute to mutual understanding between the people of the two cultures. Understanding of cultural differences and the knowledge of socio-pragmatic rules of other cultures facilitate social communication and enhances friendliness or at least minimizes confrontation. The study deals with cultural values and traditions of Iraqi and British cultures and the notion of the face as revealed in selected literary texts and ordinary daily life speech.

One culture will be different from other culture in terms of being more or less individualistic or collectivistic. In addition, dimensions are not opposites. Therefore, the culture that practises more power distance is not the opposite of the one with small power distance. It is important to note that many cultures are neither wholly low-context 
nor high-context, but instead combine the two and that the context may vary depending on the situation. However, those dimensions are of great importance as a framework for analysis and discussion.

Basically, "the United States and other western societies can be considered lowcontext societies" [1], which refers to the direct verbal communication is most often direct and the little need for nonverbal communication. [2] argues that at the core of a low-context society is the belief in the freedom of the individual, hence the term "individualistic" societies.

High-context societies include countries such as Korea, China, and Japan in Asia, Middle-Eastern countries such as Egypt, Iraq, and Iran [2: 20] and Latin American countries. Sometimes, these cultures are been referred to as collectivistic, or interdependent. Very often, these high-context cultures are hierarchical and traditional societies in which the concepts of shame and honour are much more important than they are in low-context societies [2: 56].

There are six obstacles previously proposed by Larry Barna [3] for intercultural communication to provide an appropriate answer to all questions that may arise when interacting with other cultures [3: 337]. The six obstacles include an assumption of similarities, language barriers, nonverbal misinterpretations, preconceptions, stereotypes, tendency to evaluate and high anxiety.

To understand the differences in communication among different cultures, we first need to understand the impact of culture on the patterns and forms of social and public communication. The best model that we need to follow is the one that was adopted by Geert Hofstede for studying the cross-cultural challenges in the design of interfaces. Hofstede [4: 5] states that culture is the collective programming of the mind that distinguishes the members of one group or category of people from others.

Regarding verbal communication, we can discuss two distinctive channels: content and form. For the British speaker, it is commendable to say that instead of the assertion of a personal point of view, it is advisable to initial with open questions. It is better to avoid certain topics in general such as politics, religion and the Royal family. First, the British value their privacy and may resent inquiries regarding their families or work situations [5: 9].

For the Anglo-Saxons, when A stops, B starts. On the other hand, they always attempt to prevent awkward pauses by keeping up the conversation and feel compelled to fill up the weighty silence with lively and entertaining chatter. That is why, as Kowol \& Szumieł indicate, "Eloquence is highly valued by British people, therefore they pay attention to the correctness of the language" [6: 5].

As for the British, gestures maybe considered aggressive and direct eye contact "may be misinterpreted as hostility and aggressiveness" [6: 6]. Emotions do not come out easily, which gives communicators from other cultures the impression that the British prefer to be strictly solder like and constrained.

Finally, concerning other aspects of speech, we find that the British speak in low degrees, measured tones, without raising the sound. It is not polite to interrupt others; intonation conveys one has finished speaking and, in British English, the voice normally goes down at the end of an affirmative sentence. 
For Arabic, things are extremely different about cultural patterns, customs and ways of thinking. There are many commonalities in beliefs and values shared by Arabs from different countries and social and cultural backgrounds. The generally shared cultural attitudes have remained constant because Arab society is more conservative and demands conformity from its members [7: 73].

Non-Arabs communicating with Arabs should be able to recognize the dominant cultural patterns. Although Iraq is a secular country, the traditional Islamic culture predominates, with Quranic Law playing an active role in the day-to-day life in the country.

The following concepts which are the atomism, faith, the desire for reality, justice and equality, the madness of greatness, and the importance of the family on the selfcare the fundamentals of the Arab culture. Arabs tend to see the world and events as isolated incidents, snapshots, and particular moments in time [7: 73]. This is a key psychological feature of Arab culture. It is important to point out that it is memory, not necessarily history, is the important aspect.

The belief among Arabs is that all things in life are the destinies, sovereignty, actions, power, weakness, and greatness, failure and success of humankind, many of which controlled by the will of God (fate). Arabs express emotion in a forceful, animated and exaggerated fashion. Their desire for modernity is contradicted by a desire for tradition (especially Islamic tradition, since Islam, is the one area free of Western identification and influence), as in the example of desiring democracy and modernization [7: 75].

According to Western standards, Arabs may seem so paranoid that Arabs always suspect US intentions in their territories, carefully consider the approach of US forces in the region is the basis of dealing with them. Some Arabs treat all Westerners as spies, especially those working in ethnically and sectarian diverse regions.

The fundamental phenomena identified for the introductory communication texts are the first that discovered by scholars. Feghali [8] organizes these into "three main themes: (a) basic cultural values, (b) language and verbal communication, and (c) nonverbal and paralinguistic patterns" [8: 351].

Arab cultures involve high power distance, high collectivism, low masculinity and high uncertainty avoidance. Hofstede suggests that Arab cultures display a lower masculinity than western cultures [9: 5].

Arabic of the Quran, Islam's Holy Book is considered to be the highest and unequalled level of language. Almaney \& Alwan [10: 91-96] while the other forms of Arabic as modern standard Arabic is the language of governments, media, public and religious speakers. However, the language of everyday interaction is colloquial Arabic dialect, which has developed within countries because of the variability of local dialects. It is inaccurate to assume that Iraqis, for example, readily understand one another in intercultural interaction although the observer can easily notice the variation in dialects during Iraq regions but recent research in sociolinguistics indicates that local prestigious dialects compete with the modern standard form. Also in Iraq, the variability of local dialects is not between the regions, between the south, middle, and north, or between eastern and western area but in fact between rural and urban areas. People who live 
in cities switch from their local vernacular to the dialect in a range of natural situations, which represents a kind of local standard, or prestigious of Iraqi Arabic, they started to use a prestige variety of Baghdadi Arabic that is similar to the modern standard form Abu-Haider, 1989 as cited in Feghali [8: 357]. However, for the other Arab countries, Egyptian Arabic is more readily understanding in the region than the multitude of other local dialects, mainly due to its far-reaching and popular film industry $[1 ; 2 ; 12 ; 13$ : $100-115 ; 14: 293]$ indicate that the native Arabic speakers share common features of communicative style which may conflict with styles of other language speakers such as (a) repetition, (b) indirectness, (c) elaborateness, and (d) effectiveness.

Repetition is the main feature of the Arabic discourse that has diagnosed by $[15 ; 55]$ because of the occurrence of this feature on the phonological level, morphological and lexical, syntactic, grammatical and semantic. In the Arabic marketplace or Souq "transactions are marked by language in which reiterations of pious formulas and the swearing of religious oaths on the Quran and the Prophet are an integral part. The fact that they are conventional, are formulas, are constantly and automatically produced is a testimony to their absorption into life and not to a superficiality or insignificance" [16: 177].

Such pious formulas include inshallah (by God will), el hamdullilah, hamdillah, kathirkhaiallah and ishkurallah (Thanks be to God), and sm'allah (In the name of God). Arabs behaviours and complimenting tendencies to use considerably more proverbs and preceded ritualistic phrases to praise others [17: 30]. This complimenting behaviour indicates that there are stabled rules in greeting each other. For instance, the one person walking greeting the two and the sitting as well, the riding greeting the walking, the observing of this respect watching. that all Arabs, Muslim or non-Muslim using the word As Salam Alaikum (peace be with you) and replying Wa'alaikum As Salam WarahmatulAlah Wabarakatuh following the holy Quran instruction 'And when you are greeted with a prayer, greet ye with a better prayer or at least return it Surely, Allah takes account of all things' (Al-Nisa:87) [18]. While language reformers have indicated that, the Arabic language should accommodate for greater precision and simplicity. These rules indicate that repetition is at the very heart of the language and discourse.

Another characteristic of the Arab discourse is the indirectness of communication in the Arab communication style, which indicates the concealment of the speaker of the real demands or needs or objectives during the speech [12;19: 100]. This characteristic is associated with Hofstede's [9] high vs. low context communication. Arab communities have labelled high context, with little information coded explicitly in a message but present in the physical context or internalized in the interactant's, for the members of high context cultures, courtesy and face-saving is more important than what westerns consider truthfulness. In other words, interactant's may respond in agreeable or pleasant ways, when director factual answers might prove embarrassing or distressing. In contrast, Hofstede also indicates that western societies have characterized as low context, in which interactant's clearly express their ideas or thoughts, even if the content may be harsh, uncomfortable, and unnecessarily straightforward.

Labelled genres of speech illustrate this tendency toward indirectness-directness. Iraqi Arab use be Saraha (meaning frankly, to accommodate and go along with Mubasher 
(forthright) or face to face is to let the individual speak his or her mind under any circumstances, firm in the belief that expressing oneself openly prove to be the most effective strategy, whatever the circumstances [20: 112].

The rich expressive use of language elaborated as the third characteristics of Arab communicative style where the English can adequately express an idea in ten words while the Arabic speaker will typically use one hundred words. It might be more effective to simply state that native Arabic speakers may use substantially more words to communicate verbally than do speakers of some other languages [8: 359].

The elaborateness of Arab communicative style contributes to our perception that we have two rhetorical patterns such as مبالغة (mubalagha) meaning exaggeration and التوكيد (Al tawked) meaning emphasis serve a crucial function of regulating credibility during an interaction. Arabs forced to exaggerate and over-assert in their communicative style. Non-Arabs (unaware of the speaker's linguistic tradition and style) are likely to misunderstand his intent and thus attribute a great deal of importance to the over-stressed argument. In addition, when non-Arabs speak, simply and elaborately, the Arabs. Suleiman [14: 293] do not believe them. Consider the following examples from our daily speech extracted from Iraqi drama dialogue.

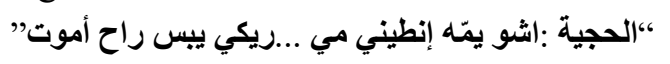

The Old Lady (Hajia): Hey, mum. Give me some water. My throat is dry. I am going to die... [21: 4].

$$
\text { اراهيم:اخ راح اموت }
$$

Ibrahim: Akh, I am going to die.

Many researchers such as Prothro (1955) and [11] indicate and identify that elaborateness of speech as an area of problematic intercultural communication inclined to two main problems with English, lack of knowledge of language appropriate for formal and informal situations and performance of social rituals but English believed that Arab had problems:

"Expressing ideas clearly and concisely" but in fact both felt that Arabs encountered difficulties in "repeating, paraphrasing or clarifying information" [8: 360].

According to Johnstone-Koch [15: 55], Arabs effectively and currently use "presentation" persuasion, in which people and not ideas are responsible for influence. The argumentation of Arabs structured by the notion that is the presentation of an idea, that is persuasive, not the logical structure of proof, which Westerners see behind the words. Repeated words, phrases and rhythms move others to believe, rather than the quasilogical style of Western logic, where interlocutors use ideas to persuade. Finally, one's status or use of language is not as relevant, and decisions are not a matter of individual choice if a claim is true. Johnstone (1989:151) suggests that presentation persuasion often employed in cultural settings in which religion is central, settings in which truth is bringing to light rather than created out of human rationality.

An array of value has been addressed by scholars been considered prevalent in Arab societies: endurance and rectitude [22: 128]; loyalty and dignity [23]; generosity, courage, and self-respect [24: 5]; and pride, rivalry and revenge [10: 96 -96]. The basic values 
most commonly mentioned include (a) collectivism, (b) hospitality, and (c) honour. The influence of Bedouin values remains strong, despite the fact that around $90 \%$ of the population in the region presently resides in villages or cities [24: 7].

The honour of the Iraqi is a supreme value cherished and protected by the Iraqi as well as put it above anything else, sometimes even circumventing the need to keep alive. Criticism, even constructive criticism, can threaten or damage an Iraqi's honour; it will be consider as a personal insult. The Arab above all protects himself and his honour from this critical onslaught. Therefore, when an Iraqi confronted by criticism, you can expect him to react by interpreting the facts to suit himself or flatly denying the facts. Criticism or corrective remarks should be been avoided, and praise would give good reaction from Iraqis. There is a considerable effect of appearances and ways of politeness used during communication. This would result in sacrificing the validity of a statement in an act of communication. So, even for simple and direct questions like, 'Do you understand?' the answer would not always reflect the truth, as "the Iraqi's preoccupation with appearances and politeness automatically requires that the answer 'yes' whether it is true or not' (Batiste, 2012: 3-1).

It is possible to say, "A flat 'no' is a signal that you want to end the relationship". The polite way for an Iraqi to say no is to say, "I'll see what I can do", no matter how impossible the task may be. After the Iraqi has queried several times concerning his success, an answer of "I'm still checking" or something similar means "no".

Honour (ash Sharaf or 'ird') and shame (al-hashma or Haya) are the most fundamental principles governing social organization and interaction in Arab societies. These concepts interwoven in so many social interactions. The duty of preserving honour affects:

"numerous aspects of social behaviour can be traced to a universal need to uphold the honour of the individual and his or her family" [25: 6].

Social status based on social ethics determined by honour and which supports relationships between families, genealogies, and tribes, can mean the difference between life and death. This concept:

"is at once a central element in the value system of the society, a method of regulating social relations, an organizing principle for social behaviour, and a means of social control" [25: 6].

The socio-psychological need to avoid a loss of face or be subject to shame, and a consequent diminution in social status in the eyes of Arabic thinking, largely, underpins social behaviour and interaction between Arabs, at least in public. It also has ramifications for the marriage possibilities of an individual and their siblings.

One of the most important facts of the Arab is the honour that is usually associated with the 'Face', which is the outward appearance of honour where Arabs describe the face as black when it undermines the honour and on the contrary, the face is described as being white when the honour is restored. A loss of face may occur when someone refuses someone else's hospitality, ignores their authority, behaves disrespectfully 
towards them, places themselves in a position of possible sexual compromise or in some other way transgresses a behavioural code:

"In order to regain honour, an individual or a family may have to resort to drastic restorative measures including blood-letting in some cases” [25: 7].

Dodd [6: 40] indicates that honour or as it called in Arabic, "ird" is a "controlling value", legitimating the family structure and the 'modesty code' required of both men and women. Honour "ird" is manifested in sexual conduct and behaviours which exhibit or regulate manliness, such as the number of sons, a man fathers and the extent of hospitality one bestows [22: 127; 27: 125].

As Mackey describes:

"One's honour determines one's image. The key to saving face is the diligent avoidance of sham".

Dodd [6: 45] claims that 'ird' appears to be a secular rather than a religious value, although diverse religious teachings have indirectly supported it. As primary possessors of 'ird', men-such as fathers, brothers, father's brothers, and paternal cousins-strictly enforce norms related to honour by ensuring that the women of their family conduct themselves properly and, thus, maintain a chaste reputation. Even if a woman has not encouraged an advance that observed by her family maybe consider dishonoured. Violations are a matter of reputation more than fact. In other words, the penalty for loss of ' $i r d$ ' is related to public acknowledgment of the violation; further, light to severe penalties, including death, must be enacted promptly to protect the 'ird' of the family.

The 'ird' of a family can be been raised or lowered, depending on the demeanour of its women (and the conduct of men towards its women). The network norms surrounding 'ird' extends too many actions that are only remotely connected with sex: loud speech, bearing, appearing in public places [6: 45].

Dodd [6: 50] posits that urbanization, political revolution, and education have not significantly changed the importance of 'ird and its related norms. To the present day, reports of "honour crimes" periodically published in contemporary media in the region. Last ten years, there are many studies of domestic abuse in Iraq, verifies that legal systems uphold this practice by failing to negatively sanction men who have killed female relatives in the name of family honour. It is reasonable to maintain, now, that dishonourable behaviour considered disruptive and threatening to the social standing of families and communities.

The strong emphasis on mutual interdependence influences social interaction patterns throughout the lifespan. Sharabi [28: 45] for instance, examines child-rearing practices in urban Muslim, middle-class families. "All mediating institutions [educational and religious], reinforce the values (and attitudes) into which the family socializes its members". The principal technique for child rearing is shaming. "He is made to feel ashamed because others see him as having acted wrongly, not because he inwardly regrets having done wrong and judges himself accordingly" [28: 248]. The proverb “" Al mawt Awla min Al Aar, meaning, "death is better than being belittled in the eyes of people" (My own translation). Shows how serious the concept of being belittled in Iraqi culture is. This is because the concept of being belittled entails 
loss of respectability among your people. If someone loses his or her respectability, he or she would ostracize. In this context, Feelings of shame in Arab societies contrast with feelings of guilt, or the internalized prohibitions against forbidden behaviour, which are more prevalent in Western societies. Because of the emphasis on extended family relations, Arab children grow up "more intimate with and sensitive to their elders than to their peers, while [mainstream] British or western children, in general, are essentially oriented toward horizontal relationships with others rather than vertical ones" [29: 386].

In addition, [8: 352] emphasizes the importance of family background and social class in determining personal status in Arab societies (as opposed to individual character or achievement). The strong sense of indebtedness to family in Arab societies generally maintained.

There is no doubt that the value of marriage in Iraqi culture is different from in English culture. An Iraqi respondent mentioned "marriage break-up" as among the actions that might cause face loss to Iraqis. Marriage break-up affects the face of the male and the female, and in most cases cause face loss to the whole family. Although the reasons and the circumstances of the break-up are different, there is one invariant fact, which is that the public self-image of the couple is affected. Such action cannot be been ignored if a divorced man or woman decides to get married again. People who want to engage in a new relationship with divorced people always seek information about the true reasons for their marriage break-up in order not to engage with people who commit serious anti-social acts and, consequently, may tarnish the name of the family.

The basic values of hospitality and generosity must be been supported in order to preserve one's honour, which becomes seriously compromised by any displays of inhospitality. The "refusal of hospitality without good reason will result in a loss of face for the host" [25: 8], as he will be shown as not fulfilling hospitality requirements.

In societies where interdependence rather than individual autonomy stressed, behaviours that enhance social relations are crucial. As Feghali states: — "Nomadic hospitality or diyafa dates to pre-Islamic times and emerged as a coping mechanism in the desert environment" [8: 351].

As the severely brutal environment makes people's life dependant on hospitality.

Arabs are generous and value generosity in others. They consider hospitality as a main factor in one's reputation. So, "Arab hospitality requires that refreshments must always be offered to guests" [24: 86].

When offering something, politeness requires that the guest "decline at least twice before accepting, and for the host to offer at least three times before finally accepting a guest's negative response" [24: 86]. Almaney and Alwan [10: 91] indicate that "To a foreigner, the Arabs' outstanding trait may well be hospitality".

Arabs raise their children highly evaluate hospitality. They implant in their children's minds that it is something upon which their reputation depends. Certain occasions require elaborate displays of hospitality. During "Marriage, burial, circumcision, and the completion of house-building; during the holy month of Ramadan, villagewide visiting and sharing of meals is common" [10:91].

Hospitality in the guest-host relationship guided by unmentioned and subtle cultural rules that depend on territoriality and the financial and social statuses of the individuals involved. Yousef (1974) indicates that social situations in Britain and West commonly 
require a verbal or written invitation, while in Arab societies, the situation is vague, complex, and defined by context. Scholars suggest, in general, that hospitality requires immediate and extensive welcomes or assistance [10;23].

Although the patterns of hospitality and visiting varied considerably according to whether members of the family are urban or rural, wealthy or poor, concentrated in one particular locality, or widely dispersed. However, Arabs expect hospitality from others, and one's personal status and reputation maybe been affected by the absence of such behaviour [30: 121].

\section{CONCLUSION}

Found that the differences between the two cultures manifested in expressions pertaining to face. In Iraqi culture, expressions and proverbs related to face are prevalent in everyday interaction. Iraqi face-related expressions - and so the examples supportive from poetry, Quran and prophets' speech classified into two groups: "Face upgrading/ honouring" and "face demeaning/threatening". Face upgrading/honouring expressions connected with honourable actions and used to uphold face, whereas face demeaning/ threatening expressions are associated with disreputable actions and used to dishonour face. In British culture, on the other hand, face-related expressions not frequently mentioned, and so they are not as popular as in Iraqi culture.

Face-enhancing acts in British and Iraqi cultures connected with praising one's achievements and one's skills irrespective of the nature of the act. It also found that the face of the person could be been enhanced by the behaviour of the people around him or her.

Losing face seen to be an area of both similarity and difference between British and Iraqi cultures. In both cultures, a face is lost because of someone's inability to meet certain expectations. It also found that in the two cultures, the group of people or family connection to the person might cause him or her to lose face, albeit this is clearer in Iraqi culture.

The findings illustrate that the Iraqi people sometimes have a tendency toward indirectness-directness throughout their common speech [20: 113]. From my personal experience, I found that is possible for Arab to use both direct and indirect communication depending on the context as well as positive and negative comments about personal appearance such as hairstyle, clothing, and jewellery, are often direct. A tendency toward indirectness in various cultural settings is relative to such issues as social practices, notions of responsibility or commitment, conceptions of truth and personhood and attitudes toward interpersonal life.

One of the findings suggests that the British are high-context when it comes to personal relationships and the maintaining of a group harmony. The British are very biased when it comes to this subject. Non-British may describe the British "as cold, distant, severe and inexpressive" [5: 133] because they are both polite from one side, but offended when they feel they do not receive the social interest they expect from others. Fox [5] argues that the British obsession with politeness is in fact only a matter of almost involuntary deeply ingrained manners. Goffman (1967a) [31] states,

"We enact the characteristics that go along with some line in an interaction and others act toward us in ways that sustain that image". 
In this way, we decipher this and hereby understand that the British reserve and social dis-ease are realized through the British behaviour in which they judge each other by themselves and assume that everyone else must feel the same way and therefore ignore them.

The British have remarkably many traits in common with the obvious high-context cultures such as Japan and countries from the Arabs world, but that is as far as the comparison goes. The British are not high-context but nor are low-context. The final statement of this research is that the British are a predominantly low-context culture but with many high-context traits in varying degrees depending on the situation. The British are "higher up the scale" than their Northern European neighbours and though not being frightfully different, the differences are significant enough to cause problems in crosscultural interactions.

According to the aforementioned, therefore, we can say that learning a language is learning the behaviour of a given society and its cultural customs. An individual language speaker's effectiveness in a foreign language directly related to his/her understanding of the culture of that language. Language carries within it all the cultural values that developed with its development.

(C) Mohammed A. Ali AlFuadi

Date of receipt 06.03.2018

Date of receipt 23.07.2018

\section{REFERENCES}

1. Rosenberg, S. (2004). "Face" Beyond Intractability. In: Conflict Information Consortium. University of Colorado, Boulder. URL: http://www.beyondintractability.org/essay/face (accessed: 14.06.2017).

2. Cohen, R. (1987). Problems of intercultural communication in Egyptian-American diplomatic relations, International Journal of Intercultural Relations, II, 29-17.

3. Barna, L. (1994). Stumbling Blocks in Intercultural Communication. In: Intercultural Communication. Publishing Company. pp. 337-346.

4. Hofstede, G.J. (2005). Cultures and organizations: Software of the mind. New York: McGraw-Hill.

5. Fox, K. (2004). Watching the English - The Hidden Rules of English Behaviour. London: Hodder \& Stoughton.

6. Kowol, A. \& Szumieł, E. (2007). United Kingdom: communication, negotiations and cultural background. URL: http://works.adamkowol.info (accessed: 15.06.17).

7. Faour, M. (1993). The Arab world after Desert Storm. Washington, DC: United States Institute of Peace Press.

8. Feghali, E. (1997). Arab Culture Communication Patterns. International Journal of Intercultural Relations, 21(3), 345-378.

9. Hofstede, G.J. (1984). Culture's consequences: International differences in work-related values. Beverly Hills, CA: Sage Publications.

10. Almaney, A. J. \& Alwan, A.J. (1982). Communicating with the Arabs: A handbook for the business executive. Prospect Heights, IL: Waveland Press.

11. Adelman, M. \& Lustig, M. (1981). Intercultural communication problems as perceived by Saudi Arabian and American managers. International Journal of Intercultural Relations, 5, 349-364.

12. Gudykunst W.B. (Ed.). (1988). Theories in intercultural communication. Newbury Park: Sage.

13. Ting-Toomey, S. (1988). Intercultural conflict styles: A face-negotiation theory. In Theories in intercultural communication. Newbury Park: Sage. pp. 213-235.

14. Suleiman, M.W. (1973). The Arabs and the West: Communication gap. In Intercommunication among nations and peoples. New York: Harper \& Row. pp. 287-303. 
15. Johnstone-Koch, B. (1983). Presentation as proof. The language of Arabic rhetoric. In: Anthropological Linguistics, 25(1), 47-55-60-151.

16. Gilsenan, M. (1983). Recognizing Islam: Religion and society in the modern Arab world. New York, NY: Pantheon Books.

17. Wolfson, N. (1981). Compliments in cross-cultural perspective. TESOL Quarterly, 15(12), $117-124$.

18. Maulawi A. (2004). The Holy Quran, Arabic Text and English Translation. Islam International Publication LTD.s

19. Ting-Toomey, S. \& Kurogi, A. (1998). Face work competence in intercultural conflict: An updated face-negotiation theory. International Journal of Intercultural Relations, 22, 187-225.

20. Katriel, T. (1986). Talking straight: Dugri speech in Israeli Sabra culture. Cambridge: Cambridge University Press.

21. Salem, T. (1967). Al Jisr: Iraqi Arabic play. Al Wazeriya, Baghdad: AL Masader press.

22. Khalid, M. (1977). The sociocultural determinants of Arab diplomacy. In: Arab and American cultures Washington, DC: American Enterprise Institute for Public Policy Research. pp. 123-142.

23. Nydell, M. (2006). Understanding Arabs: A Guide for Modern Times. Intercultural Press: Nicholas Brealey Publishing.

24. Patai, R. (1983). The Arab mind (Revised Ed). New York: Charles Scribner's Sons.

25. The UK Government website (2007). The Arab World: An Introduction to Cultural Appreciation. URL: https://www.gov.uk/government/uploads/system/uploads/attachment_data/file/HYPERLINK (accessed: 15.01.2018).

26. Dodd, P.C. (1973). Family honour and the forces of change in Arab society. International Journal of Middle East Studies, 4, 40-54.

27. Mackey, S. (1987). Saudis: Inside the desert kingdom. New York: Signet.

28. Sharabi, H. (1977). Impact of class and culture on social behaviour: The feudal bourgeois family in Arab society. In: Psychological Dimensions of Near Eastern studies Princeton, NJ: The Darwin Press. pp. $240-256$.

29. Yousef, F.S. (1974). Cross-cultural Communication: Aspects of Contrastive Social Values between North Americans and Middle Easterners. In: Human Organization: Winter 1974, Vol. 33(4). pp. 383-387.

30. Eichelman, D.F. (1981). The Middle East: An anthropological approach. Englewood Cliffs, NJ: Prentice-Hall.

31. Goffman, E. (1967). On face-work: an analysis of ritual elements in social interaction. In: Interaction Ritual: Essays on Face-to-Face Behaviour. New York: Pantheon Books. pp. 5-45.

\title{
ЯЗЫК И КУЛЬТУРА: КОНТЕКСТЫ НА АНГЛИЙСКОМ И ИРАКСКОМ АРАБСКОМ ЯЗЫКАХ
}

\author{
Мухаммед Ахмед Али Альфуади
}

Открытый учебный колледж, Центр ад-Дивания, Ирак

Использование языка во взаимодействии влечет за собой нечто большее, чем просто обмен информацией о реалистичных идеях и объектах между людьми; это важный процесс, в котором отношения между людьми излагаются и обсуждаются. Любой язык относится к определенной 
культуре, поэтому изучение любого языка не означает изучение только грамматики и лексики этого языка, но на самом деле это изучение поведения и обычаев общества, а также характеристик, которые отличают это сообщество от других. Общение между людьми происходит через прямые языковые послания и другие послания, обозначаемые культурными особенностями, которые понимаются только через знание специфических для общества закономерностей, которые их породили. Идеальные и сложные отношения между языком и культурой показывают нам, что язык тесно связан с культурой, которые влияют друг на друга, развиваются вместе и в конечном итоге формируют то, что значит быть человеком. Поэтому, принимая участие в беседах, люди сознательно или бессознательно показывают свою идентичность, свое отношение к определенной культуре или группе, а также свое намерение сблизиться или отделить себя от других людей. Используя язык, люди определяют свои отношения друг с другом и идентифицируют себя как часть социальной группы, подразумевая, что язык - это культура, а культура — это язык.

Ключевые слова: культурная коммуникация, обычаи, культурные различия, социально-прагматики, понятие лица

\section{БИБЛИОГРАФИЧЕСКИЙ СПИСОК}

1. Rosenberg S. "Face" Beyond Intractability // Conflict Information Consortium. University of Colorado Boulder. Posted: February, 2004. URL: http://www.beyondintractability.org/essay/face (accessed: 14.06.2017).

2. Cohen R. Problems of intercultural communication in Egyptian-American diplomatic relations // International Journal of Intercultural Relations, 1987. no II. 29-17.

3. Barna L. Stumbling Blocks in Intercultural Communication // Intercultural Communication. Publishing Company. pp. 337-346. 1994. URL: http://pharmacy304.pbworks.com/f/Barna,+ L.M.+(1994).pdf (accessed: 14.06.2017).

4. Hofstede G.J. Cultures and organizations: Software of the mind. New York: McGraw-Hill, 2005.

5. Fox K. Watching the English - The Hidden Rules of English Behaviour. London: Hodder \& Stoughton. 2004.

6. Kowol A., Szumiet E. United Kingdom: communication, negotiations and cultural background. 2007. URL: http://works.adamkowol.info (accessed: 15.06.17).

7. Faour M. The Arab world after Desert Storm. Washington, DC: United States Institute of Peace Press, 1993.

8. Feghali E. Arab Culture Communication Patterns // International Journal of Intercultural Relations, 1997. no. 21(3). pp. 345-378.

9. Hofstede G.J. Culture's consequences: International differences in work-related values. Beverly Hills, CA: Sage Publications, 1984.

10. Adelman M., Lustig M. Intercultural communication problems as perceived by Saudi Arabian and American managers // International Journal of Intercultural Relations, 1981. no 5. pp. 349-364.

11. Almaney A.J., Alwan A.J. Communicating with the Arabs: A handbook for the business executive. Prospect Heights, IL: Waveland Press, 1981.

12. Gudykunst W.B. (Ed.) Theories in intercultural communication. Newbury Park: Sage, 1988.

13. Ting-Toomey $S$. Intercultural conflict styles: A face-negotiation theory // Theories in intercultural communication. Newbury Park: Sage, 1988. pp. 213-235.

14. Suleiman M.W. The Arabs and the West: Communication gap // Intercommunication among nations and peoples. New York: Harper \& Row. 1973. pp. 287-303.

15. Johnstone-Koch B. Presentation as proof. The language of Arabic rhetoric. Anthropological Linguistics. 1983. no 25(1). pp. 47-60.

16. Gilsenan, M. Recognizing Islam: Religion and society in the modern Arab world. New York, NY: Pantheon Books. 1983. 
17. Wolfson N. Compliments in cross-cultural perspective // TESOL Quarterly. 1981. no 15(12). pp. $117-124$.

18. Maulawi S.A. The Holy Quran, Arabic Text and English Translation. Islam International Publication LTD. 2004.

19. Ting-Toomey S., Kurogi A. Face work competence in intercultural conflict: An updated facenegotiation theory // International Journal of Intercultural Relations. 1998. no 22. pp. 187-225.

20. Katriel T. (1986). Talking straight: Dugri speech in Israeli Sabra culture. Cambridge: Cambridge University Press.

21. Salem T. Al Jisr: Iraqi Arabic play. Al Wazeriya, Baghdad: AL Masader press. 1967.

22. Khalid M. The sociocultural determinants of Arab diplomacy // Arab and American cultures. Washington, DC: American Enterprise Institute for Public Policy Research. 1977. pp. 345-378.

23. Nydell M. Understanding Arabs: A Guide for Modern Times. Intercultural Press: Nicholas Brealey Publishing. 2006.

24. Patai R. The Arab mind (Revised Ed). New York: Charles Scribner's Sons. 1983.

25. The UK Government website The Arab World: An Introduction to Cultural Appreciation. 2007. URL: https://www.gov.uk/government/uploads/system/uploads/attachment_data/file/ HYPERLINK (accessed: 15.01.2018).

26. Dodd P.C. Family honour and the forces of change in Arab society // International Journal of Middle East Studies. 1973. no 4. pp. 40-54.

27. Mackey, S. Saudis: Inside the desert kingdom. New York: Signet, 1987.

28. Sharabi $H$. Impact of class and culture on social behaviour: The feudal bourgeois family in Arab society / Psychological Dimensions of Near Eastern studies. Princeton, NJ: The Darwin Press, 1977. pp. $240-256$.

29. Yousef F.S. (1974). Cross-cultural Communication: Aspects of Contrastive Social Values between North Americans and Middle Easterners // Human Organization: Winter. 1974. no 33(4). pp. $383-387$.

30. Eichelman D.F. The Middle East: An anthropological approach. Englewood Cliffs, NJ: PrenticeHall. 1981.

31. Goffman E. On face-work: an analysis of ritual elements in social interaction // Interaction Ritual: Essays on Face-to-Face Behaviour. New York: Pantheon Books, 1967. pp. 5-45.

\section{Для цитирования:}

Мохаммед А. Али АльФуади Язык и культура: контексты на английском и иракском арабском языках // Вестник Российского университета дружбы народов. Серия: Теория языка. Семиотика. Семантика, 2018. Т. 9. № 3. С. 761-773. doi: 10.22363/2313-2299-2018-9-3-761-773.

\section{For citation:}

Mohammed Ahmed Ali AlFuadi (2018). Language and Culture: Contexts in British English and Iraqi Arabic. RUDN Journal of Language Studies, Semiotics and Semantics, 9(3), 761-773. doi: 10.22363/2313-2299-2018-9-3-761-773.

\section{Сведения об авторе:}

Мохаммед Ахмед Али Альфуади, ассистент лектора, отдел английского языка, Открытый учебный колледж Эд-Дивании, Ирак; научные интересы: социолингвистика, теория дискурсивного анализа, социально-прагматика; e-mail: mohammedalfuadi@yahoo.co.uk

\section{Information about the author:}

Mohammed Ahmed Ali AlFuadi, Assistant Lecturer in the Department of English Language, Open Educational College, Ad-Diwaniya Center; Interests: sociolinguistics, discourse analysis theory, socio-pragmatics; e-mail: mohammedalfuadi@yahoo.co.uk 